Journal of Reproduction and Development, Vol. 39, No. 4, 1993

\title{
Formation of Ovary-Like Multitissue Spheroids Composed of Isolated Rat Follicles In Vitro
}

\author{
Noboru MURAKAMI, Osamu AKAGUMA, Takayuki MURAKAMI'1), \\ Kouei SUGITA, Miki TANIGUCHI, Haruto KURODA and \\ Teiichi ETOH
}

Departments of Veterinary Physiology and ${ }^{1)}$ Anatomy, Faculty of Agriculture, University of Miyazaki, Miyazaki 889-21, Japan

\begin{abstract}
Intact preantral follicles were isolated from immature rat ovaries by enzymatic dissociation and cultured in Dulbecco's modified Eagle's medium (DMEM) supplemented with 10\% fetal calf serum. The globular shape of the follicles was maintained during culture for $96 \mathrm{~h}$ on agar-coated plates. When the follicles were placed near the center of the plates, follicles assembled, being in close contact with each other $24 \mathrm{~h}$ after culture and after $48 \mathrm{~h}$ large spheroidal tissues had formed. Histological examination revealed that these tissues possessed many intact follicles with preserved oocytes and many differentiated cells filled the gaps between follicles. The layer resembled squamous epithelium covered this spheroidal tissue. Culture in serum-free DMEM resulted in follicle assemblage but not formation of ovary-like multitissue spheroids (ovarioids). On the other hand, fetal calf serum induced ovarioid formation in a concentration-dependent manner as did the fraction containing the 30-100-kDa protein from fetal calf serum. Protein and RNA synthesis inhibitors inhibited ovarioid formation. The formation of ovarioids from isolated ovarian follicles may prove to be a useful model to study the ovarian cell-cell or tissue-tissue attachment and the cell differentiation in vitro.
\end{abstract}

Key words: Ovary, Tissue culture, Follicle.

(J. Reprod. Dev. 39: 293-299, 1993)

$\mathbf{T}$ he mammalian ovary contains various components, such as follicles at different developmental stages, corpora lutea and interstitial cells which synthesize steroids and water soluble substances including inhibin and several growth factors, independently or interdependently during the various reproductive stages [1-6]. Techniques of follicular isolation by enzymatic digestion and follicular culture have been developed with the aim of clarifying the mechanisms involved in follicular development and oocyte maturation in vitro [7-11]. With conventional cell culture systems, ovarian follicles became attached to the plates, losing their globular shape and finally the granulosa cells spread out uniformly around the

Accepted for Publication: June 22, 1993

Correspondence: N. Murakami oocytes, so the culture conditions required to maintain normal follicular shape have been studied [7, 8]. Roy and Greenwald [10] showed that the follicular globular shape was maintained in culture using plates pre-coated with agar which eliminates the surface charge. In this study, we investigated several culture systems in vitro and found that the cultured follicles contacts each other and finally form multitissue ovary-like spheroids (ovarioids). Histological examination revealed that each multitissue spheroid was surrounded by a surface epithelium and contained many follicles and differentiated cells. Therefore, we tested several factors which contributed to ovarioid formation. 


\section{Materials and Methods}

\section{Animals}

Twenty-five-day-old Sprague Dawley rats bred in our laboratory were used and kept in a constant-temperature room $(23 \pm 1$ C) under a $\operatorname{light}(\mathrm{L})$ : $\operatorname{dark}(\mathrm{D})$ regimen of $14 \mathrm{~L}: 10 \mathrm{D}$ (lights on from $0500-1900 \mathrm{~h}$ ). They were allowed free access to food and drinking water. Vaginal opening in this colony was observed on day $37 \pm 0.3$ (mean $\pm \mathrm{SE})$.

\section{Plate coating}

The culture dishes used were 24-well multiplates (\#3047, Falcon) and primaria plates (\#3847, Falcon). The bottom surfaces of the latter are treated so that they are positively charged [13]. All the dishes were coated with $0.7 \%$ agar (Nakarai Chem, Tokyo) unless stated otherwise. To determine the effects of various coating substances on multitissue speroid formation, the following materials were used: $0.2 \mathrm{ml}$ collagen $(0.5 \mathrm{mg} / \mathrm{ml}$, Sigma), $0.3 \mathrm{ml}$ laminin $(0.01 \mathrm{mg} / \mathrm{ml}$, Sigma $), 0.3 \mathrm{ml}$ poly-1-ornithine $(0.01 \mathrm{mg} / \mathrm{ml}$, Sigma $), 0.3 \mathrm{ml}$ fibronectin $(0.01 \mathrm{mg} / \mathrm{ml}$, Sigma) and $0.7 \%$ agars (agarose \#50013R, Marien Colloid Inc.; agarose L \#252017A, Oreo Co; bactoagar \#0140-01 and agar Nobel \#0142-01, Difco Lab; agar \# MIF1524, M9G5614 and purified agar \#01056, Nakarai Chem).

\section{Follicle collection and culture}

The rats anesthetized with pentobarbital sodium were killed by decapitation. Ovaries were removed and washed with Hank's salt solution (Gibco) containing $100 \mu \mathrm{g} / \mathrm{ml}$ gentamicin (Funakoshi Corp, Tokyo) for $3 \mathrm{~min}$, then the fatty fragments were removed. The ovaries were minced into small pieces and placed in $10 \mathrm{ml}$ Hank's solution containing collagenase (Type IV, $2 \mathrm{mg} / \mathrm{ml}$, Sigma), pronase $(0.25 \mathrm{mg} / \mathrm{ml}$, Sigma) and deoxyribonuclease (DNAse, $0.05 \mathrm{mg} / \mathrm{ml}$, Sigma). The tissues were incubated for $10 \mathrm{~min}$ at $37 \mathrm{C}$ in a shaking water bath, and were pipetted gently through Pasteur pipettes, then incubated for further 10 min at $37 \mathrm{C}$ with the same enzyme solution. After retrituration through pipettes, the incubation tubes were allowed to settle for $1 \mathrm{~min}$. During this $1 \mathrm{~min}$ settlement, antral follicles and undigested fragments go to the bottom. The supernatant fraction containing isolated preantral follicles was collected and centrifuged for $3 \mathrm{~min}$ at $500 \times \mathrm{g}$ and the resulting tissue pellet was resuspended in fresh culture medium. The tissues remaining were resuspended in fresh isolation medium and dissociated further, as described above. Resulting isolated follicles were washed twice with $5 \mathrm{ml}$ Hank's salt solution and transferred to Dulbecco's modified Eagle's medium (DMEM, Gibco) with 10 $\mathrm{mM} \mathrm{N}$-2-hydroxyethylpiperazine-n-2-ethanesulfonic acid (HEPES, Gibco), $1.25 \mathrm{mg} / \mathrm{ml} \mathrm{NaHCO} 3,10$ $\mu \mathrm{g} / \mathrm{ml}$ gentamicin and $10 \%$ fetal calf serum (Gibco), unless stated otherwise. About 70-80 follicles/ $1.5 \mathrm{ml}$ culture medium were placed near the centers of the culture dishes and maintained in an incubator at $37 \mathrm{C}$ with $95 \%$ air and $5 \% \mathrm{CO}_{2}$. To test the effects of various substances on ovarioid formation, following materials were added to serum free-medium alone or in combinations written in the results: $100 \mu \mathrm{g} / \mathrm{ml}$ human transferrin, $5 \mu \mathrm{g} / \mathrm{ml}$ insulin, $100 \mu \mathrm{M}$ putrescine, $20 \mathrm{nM}$ progesterone, $30 \mathrm{nM}$ selenium, $10 \mathrm{nM}$ hydrocortisone, $20 \mu \mathrm{g} / \mathrm{ml}$ epidermal growth factor, $1 \mu \mathrm{g} / \mathrm{ml}$ vitronectin, $2.5 \mu \mathrm{g} / \mathrm{ml}$ fibronectin, $25 \mathrm{ng} / \mathrm{ml}$ cycloheximide and $75 \mathrm{ng} / \mathrm{ml}$ actinomycin $\mathrm{D}$.

\section{Ultrafiltration of fetal calf serum}

To determine which of its components were involved in ovarioid formation, fetal calf serum was divided into fractions of various molecular sizes using ultrafilters $(300,100$, and $30 \mathrm{kDa}$; Millipore) and each was added to the culture medium at concentrations equivalent to $10 \%$ fetal calf serum. A sample of each fraction was subjected to sodium dodecyl sulfate-polyacrylamide-gel electrophoresis (SDS-PAGE) using the method described by Dunba [12].

\section{Histology}

The ovarioids were fixed with $4 \%$ formaldehyde, embedded in paraffin, sectioned at $4 \mu \mathrm{m}$ thickness and stained with hematoxylin-eosin or azan for histological examinations.

\section{Results}

Freshly isolated follicles each possessed a theca, follicular epithelium, granulosa cells and oocytes. When preantral follicles were scattered everywhere and cultured with DMEM supplemented 
with $10 \%$ fetal calf serum on plates coated with $0.7 \%$ agar, the globular shape of follicles was maintained for $96 \mathrm{~h}$. When the follicles were placed near the centers of the plates (Fig. la), the follicles had assembled and were in close contact with each other after $24 \mathrm{~h}$ of culture (Fig. 1b) and after $48 \mathrm{~h}$ of culture large spheroidal tissues with diameters of approximately $1 \mathrm{~mm}$ had formed on all the agar-coated plates (Fig. 1c). Histological

examination revealed that they contained several follicles with granulosa cell layers surrounding the oocyte (Figs. 1d, e), and differentiated cells filled the gaps between these follicles (Fig. 1d). The exterior of each spheroid was covered with a layer that resembled squamous epithelim (Fig. 1f).

We investigated how different conditions affected multitissue spheroids formation from the cultured follicles by changing the type of culture

b
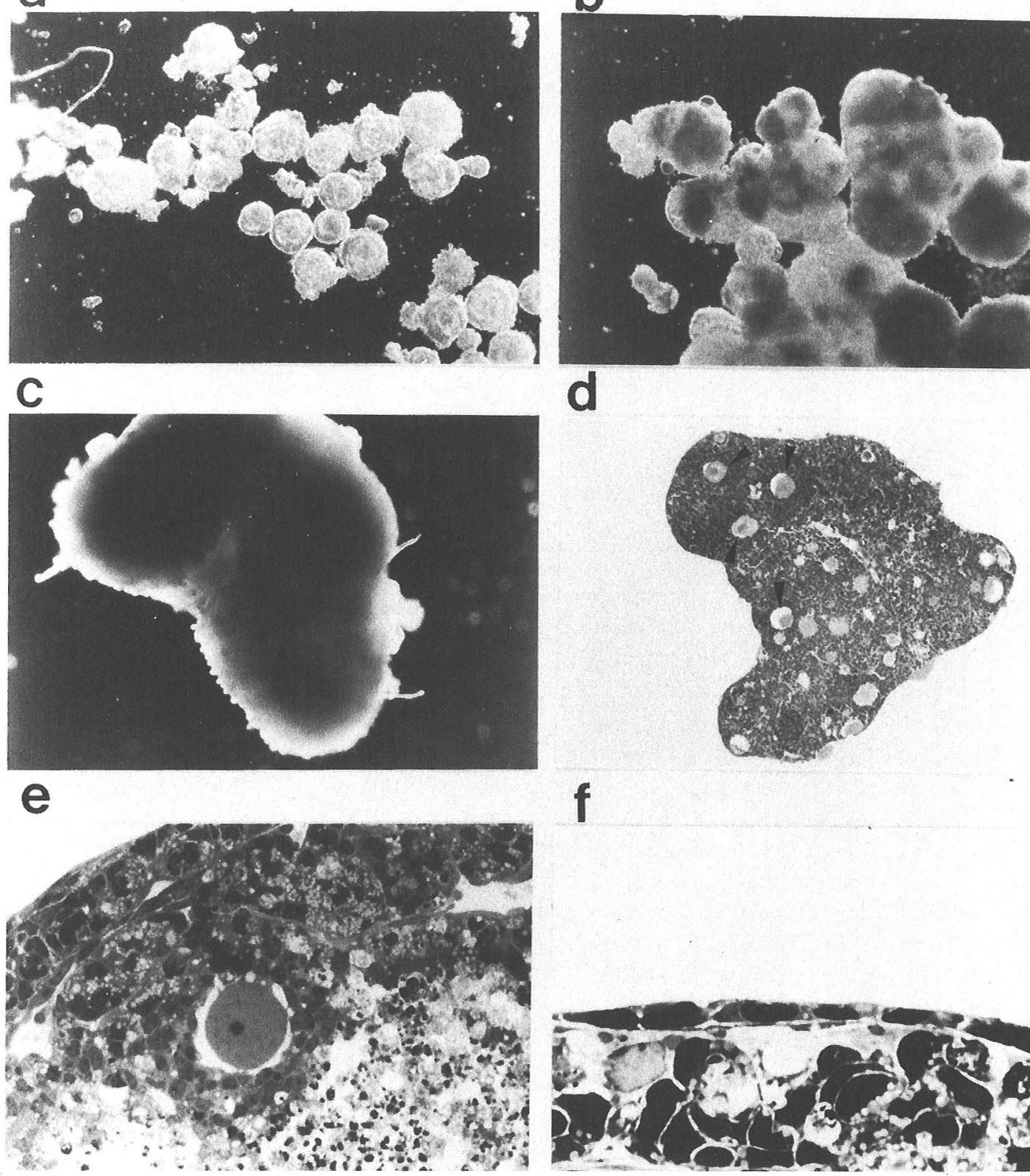

d

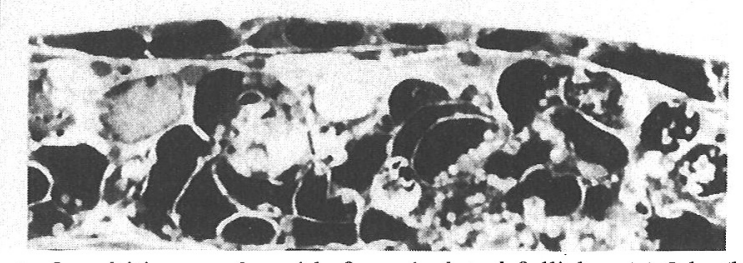

Fig. 1. Phase-contrast microscopic features of development of multitissue spheroids from isolated follicles. (a) $2 \mathrm{~h}$; (b) $24 \mathrm{~h}$; (c) $48 \mathrm{~h}$ after culture of follicles in agar plate. (d) A 4- $\mu \mathrm{m}$ section of a multitissue spheroid stained with hematoxylin and eosin. Arrowheads indicate oocytes. (e) Magnified view of a follicles in ovarioid. (f) Magnified view of layer resembling epithelium. Magnification; (a) $\times 50$, (b) $\times 75$, (c) $\times 75$, (d) $\times 75$, (e) $\times 500$, (f) $\times 750$. 
Table 1. Percentages of follicle assemblages and formation of ovariods (/ no. tested wells) in plates coated with various substances

\begin{tabular}{llcc}
\hline plate & coating substance & $\begin{array}{c}\text { \% of wells showing } \\
\text { follicle assemblage* }\end{array}$ & $\begin{array}{c}\text { \% of wells with } \\
\text { ovarioids* }\end{array}$ \\
\hline$\# 3047$ & none $(\mathrm{n}=10)^{* *}$ & 0 & 0 \\
& collagen $(\mathrm{n}=18)$ & 0 & 0 \\
& laminin $(\mathrm{n}=12)$ & 0 & 0 \\
& fibronectin $(\mathrm{n}=12)$ & 0 & 0 \\
& agar $(\mathrm{n}=36)$ & 100 & 88.9 \\
primaria & none $(\mathrm{n}=14)$ & 0 & 0 \\
& collagen $(\mathrm{n}=6)$ & 0 & 0 \\
& agar $(\mathrm{n}=12)$ & 100 & 91.6 \\
\hline
\end{tabular}

*Follicle assemblage and formation of ovarioids were evaluated at $24 \mathrm{~h}$ and $48 \mathrm{~h}$ after initiation of culture, respectively. **total numbers of wells tested.

dish, the plate coating substances and the culture medium. When follicles were cultured on plates coated with collagen or anchorage glycoproteins, fibronectin and laminin, neither follicular assemblage nor close contact was observed (Table 1). Under these conditions, follicles became attached to the bottom surface of the plates and ruptured after $24 \mathrm{~h}$ of culture and the granulosa cells spread out and surrounded oocytes. When positively charged plates (primaria) were used, neither follicular assemblage nor ovarioid formation were observed (Table 1).

The effects of various agars on ovarioid formation were examined, as crude agar may contain factors that stimulate follicular attachment and/or cell differentiation. With all the agars tested, both follicular assemblage and ovarioid formation were induced (Table 2).

When follicles were cultured on agar plates in serum-free medium supplemented with human transferrin, insulin, putrescine, progesterone, selenium, hydrocortisone or epidermal growth factor, follicle assemblage occurred in all the cultures, but ovarioid formation was not observed even when cultured for $96 \mathrm{~h}$ (Table 3). However, when the culture medium was supplemented with various concentrations of fetal calf serum, ovarioid formation was induced in a concentrationdependent manner: in the presence of 2.5, 5 and $10 \%$ fetal calf serum, multitissue spheroids formed after 4, 3 and 2 days respectively (Table 3). To determine whether protein and RNA synthesis were involved in ovarioid formation, cycloheximide and actinomycin $\mathrm{D}$, inhibitors of protein
Table 2. Effect of various agar on formation of ovarioids

\begin{tabular}{lccc}
\hline \multicolumn{2}{c}{ agar } & No. tested wells & $\begin{array}{c}\text { No. wells } \\
\text { with ovarioids }\end{array}$ \\
\hline agarose & $50013 \mathrm{R}$ & 14 & 14 \\
bactoagar & $0140-01$ & 14 & 14 \\
agarose L 252017A & 12 & 12 \\
agar & MIFI524 & 12 & 12 \\
agar M9G5614 & 14 & 13 \\
agar Nobel 0142-02 & 14 & 14 \\
agar Purified 01056 & 14 & 13 \\
\hline
\end{tabular}

*Formation of multitissue spheroids was evaluated $48 \mathrm{~h}$ after start of culture.

and RNA synthesis respectively, were added to the culture medium. Both compounds inhibited ovarioid formation, even when the culture medium contained fetal calf serum (Table 3). Therefore, it was apparent that the fetal calf serum contained some substance that induce multitissue spheroid formation. We determined whether they were specific to fetal calf serum by comparing its effects with those of other sera. Sera from a less than 10-day-old calf and from a one-year-old calf were equieffective as fetal calf serum at inducing multitissue spheroid formation. On the other hand, horse serum did not induce the ovarioid formation (Table 3).

The appearance of protein bands in SDS-PAGE after ultrafiltration of fetal calf serum revealed a good agreement with the pore size of the filter, except for those under $30 \mathrm{kDa}$ (Fig. 2). Ovarioid formation was induced in culture media containing each of the protein fractions, below $300 \mathrm{kDa}$, below $100 \mathrm{kDa}$ and over $30 \mathrm{kDa}$. However, in 
Table 3. Percentages of follicle assemblages and formation of ovarioids in culture with or without serum

\begin{tabular}{lccccc}
\hline & $\begin{array}{c}\text { \% of wells showing } \\
\text { follicle assemblage* }\end{array}$ & \multicolumn{3}{c}{$\begin{array}{c}\text { of wells with } \\
\text { ovarioids }\end{array}$} \\
& & & 2 day & 3 day & 4 day \\
\hline serum-free $(n=48)$ & 91.7 & 0 & 0 & 4.1 \\
$2.5 \%$ FCS** $(n=16)$ & 100 & 0 & 6.2 & 43.7 \\
$5 \%$ FCS $\quad(n=16)$ & 100 & 6.2 & 87.5 & 93.7 \\
$10 \%$ FCS $\quad(n=48)$ & 100 & 87.5 & 93.7 & 93.7 \\
$10 \%$ NCS $\quad(n=16)$ & 100 & 81.2 & - & - \\
$10 \%$ CS $\quad(n=16)$ & 100 & 75.0 & - & - \\
$10 \%$ HS $\quad(n=16)$ & 100 & 0 & 0 & - \\
$10 \%$ HS-H $\quad(n=16)$ & 100 & 0 & 0 & - \\
$5 \%$ FCS and $\mathrm{CH}(n=8)$ & 100 & 0 & 0 & 0 \\
$5 \%$ FCS and AD $(n=8)$ & 100 & 0 & 0 & 0 \\
\hline
\end{tabular}

* Follicle assemblage was evaluated at $24 \mathrm{~h}$ after initiation of culture. The formation of ovarioids was evaluated on days 2, 3 and 4 of culture.

** Abbreviations: FCS, fetal calf serum; NCS, new born calf serum; CS, calf serum; $\mathrm{HS}$, horse serum; HS-H, heat-inactivated horse serum; $\mathrm{CH}$, cycloheximide; AD, actinomycin D.

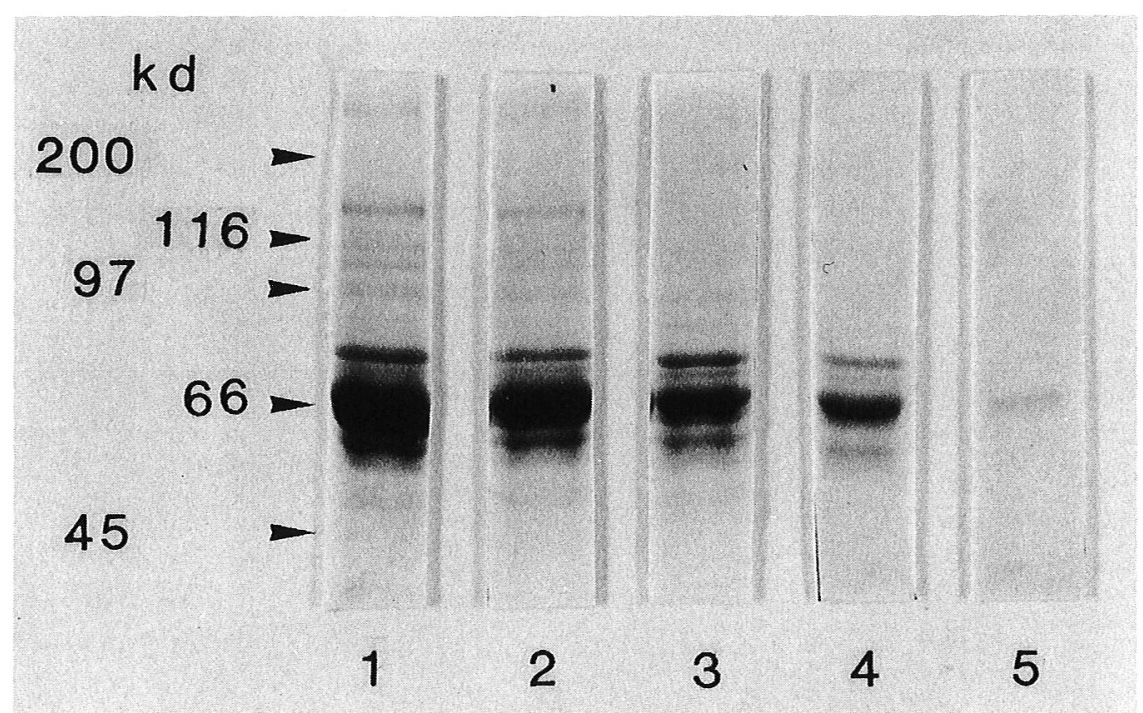

Fig. 2. Protein compositions of serum fractions obtained by ultrafiltration. Lane 1; normal fetal calf serum. Lanes $2-5$ show each fraction containing proteins with molecular weights of less than $300 \mathrm{kDa}$ (lane 2), $100 \mathrm{kDa}$ (lane 3), between 30 and $100 \mathrm{kDa}$ (lane 4), less than $30 \mathrm{kDa}$ (lane 5).

medium containing 30-100-kDa proteins, ovarioid formation was delayed for 2 days compared with control cultures and did not occur in medium containing proteins of less than $30 \mathrm{kDa}$ (Table 4). When follicles were cultured with medium supplemented with less than $30-\mathrm{kDa}$ proteins and either bovine fibronectin or vitronectin, which are major cell adhesion factors in serum, ovarioid formation was not stimulated (Table 4).

\section{Discussion}

The globular shape of follicles was maintained when culture plates were coated with agar, not with collagen or anchorage glycoproteins. The follicles ruptured and granulosa cells spread around the oocytes with the latter two coatings. These results agree with those of other workers [7-11]. It is well known that extracellular matrix 
Table 4. Effect of serum fractions obtained by ultrafiltration on the formation of ovarioids

\begin{tabular}{|c|c|c|c|}
\hline \multirow[t]{2}{*}{ fraction } & \multicolumn{3}{|c|}{ No. wells with ovarioids } \\
\hline & 2 day & 3 day & 4 day \\
\hline less than $30 \mathrm{kDa}(\mathrm{n}=4)$ & 0 & 0 & 0 \\
\hline more than $30 \mathrm{kDa}(\mathrm{n}=4)$ & 0 & 0 & 4 \\
\hline less than $100 \mathrm{kDa}(\mathrm{n}=4)$ & 0 & 0 & 4 \\
\hline less than $300 \mathrm{kDa}(\mathrm{n}=4)$ & 4 & & \\
\hline vitronectin * & 0 & 0 & 0 \\
\hline fibronectin * & 0 & 0 & 0 \\
\hline
\end{tabular}

*Vitronectin or fibronectin was added to the culture medium with less than $30 \mathrm{kDa}$ proteins.

components, such as collagen, fibronectin and laminin, permit cells to become attached to culture plates and spread to form a monolayer $[14,15]$. In the presence of such substances, thecal cells surrounding follicles may have adhered strongly to these matrix components and consequently follicles ruptured. Furthermore, primalia plate [13] whose surface was electrically charged also brought about follicle rupture. It is likely, therefore, that uncharged plates are necessary to preserve intact follicles in culture.

As we demonstrated using agar plates, the follicles assembled and were in close contact with each other after culture for $24 \mathrm{~h}$. To our knowledge, no studies have shown that cultured tissues, but not cells, assembled and formed a large tissue. The actual mechanism of follicle assemblage was not elucidated in this study. However, gravitation between the thecal cells of the follicles may be involved in this process. When the ovarian enzymatic digestion treatment was continued for a long time and mechanical pipetting for follicular isolation was vigorous, follicle assemblage was inhibited, which probably is due to the thecal cells peeling from the follicles. Furthermore, when follicles were scattered everywhere and cultured in the manner that the follicles were kept separate from each other (follicle contact at initiation of culture is not necessary for follicle assemblage), follicle assemblage was not observed.

After culture for $48 \mathrm{~h}$, spheroidal tissues were formed. This spheroidal tissue resembled the immature ovary as histological examination revealed that they contained many preserved follicles and the gaps between follicles were filled with differentiated cells. The histological findings raised the following questions; what is the nature of the differentiated cells, why does each follicle separate from the follicular assemblage, why does a layer resembling surface epithelium cover this tissue and most interestingly what causes formation of this tissue (ovarioid). As some seaweeds may contain various substances that stimulate cell growth and/or cell differentiation, we investigated the effects of different agars on the formation of the spheroidal tissue using crude and pure preparations. All the agars tested induced ovarioid formation, although in serum-free medium they did not. Therefore, ovarioid formation did not appear to be due to substances in the agars.

Culture in serum-free medium or in medium containing horse serum resulted in follicle assemblage but not ovarioid formation, which suggests that the mechanisms involved in these processes differ. However, fetal calf serum induced ovarioid formation in a concentration-dependent manner. These results indicate that some substances in calf serum but not in the horse serum are necessary for induction of ovarioid formation. Our results with fractionated serum indicated that $30-100-\mathrm{kDa}$ proteins in fetal calf serum were necessary for ovarioid formation. Although vitronectin and fibronectin are known to be major cell adhesion factors in serum [16], they did not stimulate ovarioid formation. Further study is required to elucidate which are involved in this process. The numerous differentiated cells between the follicles were probably granulosa or thecal cells, but not fibroblasts, as these cells have been shown to posses $3 \beta$-hydroxysteroid dehydrogenase ( $3 \beta$-HSD) activity by our preliminary examination using histochemical staining of $3 \beta$-HSD (data not shown).

Multicellular spheroids in which cells are in close contact with each other have been widely used for cancer research and developmental biology and are considered useful for investigations of intercellular interactions [17-20]. A multicellular spheroid has been formed from a monolayer of rat hepatocytes after culture for 4 days on plates coated with proteoglycan and bovine serum albumin and plate with a positive charge [17]. Elimination of serum factors was essential for the formation of such spheroids [17]. It would appear, therefore, that the mechanism of hepatocyte multicellular spheroid formation differs substantially from that of ovarian spheroidal tissues in our present study, as the latter required serum factors and, furthermore, was inhibited when positively charged culture plates were used. 
Cell-matrix and cell-cell interactions are important in embryonic organogenesis and for the maintenance and repair of differentiated tissues. Multicellular spheroids composed of normal cells are considered to provide a more useful in vitro model for the investigation of cell behavior regulated by high cell density in culture [17-19]. However, to our knowledge, there is no report describing spheroidal tissues that comprise several ovarian components. The present study may lead to the development of a useful model to study tissue organogenesis and cell differentiation. Furthermore, we anticipate that this ovary-like spheroidal tissue may also be useful for studies on follicular steroidogenesis.

\section{References}

1. Armstrong DT, Goff AK, Dorrington JH. Regulation of follicular estrogen biosynthesis. In: Midgley AR, Sadler WA (eds.), Ovarian Follicular Development \& Function. New York: Plenum Press; 1979: 169-181.

2. Ward DN, Glenn SD, Liu W-K, Gordon WL. Chemistry and physiology of gonadal peptide. In: Greenwald GS, Terranova PF (eds.), Factors Regulating Ovarian Function. New York: Plenum Press; 1983: 141-156.

3. Lobb DK, Dorrigton JH. Bovine thecal cells secrete transforming growth factor $\alpha$ and $\beta$. In: Hirsh AN (ed.), Growth Factors and the Ovary. New York: Plenum Press; 1989: 199-203.

4. Greenwald GS. Follicular activity in the mammalian ovary. In: Jones RE (ed.), The Vertebrate Ovary. New York: Plenum Press; 1979: 639-689.

5. Erickson GF, Magoffin DA, Dyer CA, Hofeditz C. The ovarian androgen producing cells: A review of structure/function relationships. Endocrine Rev 1985; 6: 371-399.

6. Richards JS, Jahansen T, Hedin L, Lifka J, Ratoosh S, Durica JM, Goldring NB. Ovarian follicular development: from physiology to molecular biology. Rec Prog Hor Res 1987; 43: 231-276.

7. Gore-Langton RE, Daniel SAJ. Follicle-stimulating hormone and estradiol regulate antrum-like reorganization of granulosa cells in rat preantral follicle cultures. Biol Reprod 1990; 43: 65-72.

8. Murakami N, Onoda Y, Katoh H, Murakami T, Etoh T. A separation of intact preantral follicles from rat ovary by enzymatic dissociation and filtration. Jpn J Anim reprod 1987; 33: 101-104.

9. Roy SK, Greenwald GS. An enzymatic method for dissociation of intact follicles from the hamster ovary: Histological and quantitative aspects. Biol Reprod 1985; 32: 203-215.

10. Roy SK, Greenwald GS. In vitro effects of folliclestimulating hormone, luteinizing hormone and prolactin on follicular deoxyribonucleic acid synthesis in the hamster. Endocrinology 1988; 122: 952-958.

11. Roy SK, Greenwald GS. Hormonal requirement for the growth and differentiation of hamster preantral follicles in long-term culture. J Reprod Fert 1989; 87: 103-114.

12. Dunba BS. Two-dimensional electrophoresis and immunological techniques. New York; Plenum Press; 1987.

13. Catalog issued by Becton Dickinson, 1986.

14. Carlson R, Engvall E, Freeman A, Ruoslahti E. Laminin and fibronectin in cell adhesion of cells from regenerating liver to laminin. Proc Natl Acad Sci USA 1981; 78: 2403-2406.

15. Johansson S, Hook M. Substrate adhesion of rat hepatocytes: on the mechanism of attachment to fibronectin. J Cell Biol 1984, 98: 810-817.

16. Shirayoshi Y. Functions and specificity of celladhesion factors. Saiboukougaku 1985; 4: 442-450 (in Japanese).

17. Koide N, Sakaguchi K, Koide Y, Asano K, Kawaguchi $M$, Matsusima $H$, Takenami $T$, Shinji $T$, Mori M, Tsuji T. Formation of multicellular spheroid composed of adult rat hepatocytes in dishes with positively charged surfaces and under other non adherent environments. Exp Cell Res 1990; 186: 227-235.

18. Landry J, Bernier D, Ouellet C, Goyette R, Marceau N. Spheroidal aggregate culture of rat liver cells: histotipic reorganization, biomatrix deposition, and maintenance of functional activities. $J$ Cell Biol 1985; 101: 914-923.

19. Mueller-Klieser W. Multicellular spheroids. A review on cellular aggregates in cancer research. $J$ Cancer Res Clin Oncol 1987; 113: 101-122.

20. Stein LS, Stoica G, Tilley R, Burghard C. Rat ovarian granulosa cell culture: a model system for the study of cell-cell communication during multistep transformation. Cancer Res 1991; 51: 696-706. 